\section{DOES SILDENAFIL PROTECTS THE DEVELOPING BRAIN FROM HYPOXIA- INDUCED CELL DEATH?}

M. Rogido ${ }^{1}$, J. Nirapil ${ }^{1}$, K. Nieto Aguirre ${ }^{2}$, C. Ridaura ${ }^{3}$, V. Lima²

${ }^{1}$ Atlantic Neonatal Research Institute - UMDNJ, Morristown, NJ, USA, ${ }^{2}$ Universidad Autonoma, San Luis Potosi, ${ }^{3}$ Instituto Nacional de Pediatria, Mexico, Mexico

Sildenafil isa selective inhibitorofphosphodiesterase 5 resulting in arterial vasodilation. Previous studies showed that oral sildenafil may act as a potential therapy in infants with severe PPHN. However, very little is known on the adverse effects of sildenafil, specifically on the CNS. Its administration enhances functional recovery and increases neurogenesis and vasculogenesis in the adult rat after stroke. The effects of sildenafil on the developing brain remain unknown.

Aim: To determine the effect of sildenafil on apoptotic cell death after hypoxic injury in a rat pup model.

Methods: At P10, sixteen male Wistar rat pups were randomized to receive Sildenafil $5 \mathrm{mg} / \mathrm{kg} /$ day or water three hours before being subjected to hypoxemic conditions. All animals were subjected to $\mathrm{FiO} 2$ of $10.4 \%$ for 10 minutes. On P25 animals were euthanized, brains removed, fixed, and embedded in paraffin. Immunofluorescence TUNEL staining using an apoptosis detection kit with dual labelling was performed. Results were expressed as mean $\pm S D$.

Results: All animals survived the experimental conditions. There was no significant difference in the number of double-labelled cells between the control and the sildenafil-treated group (93 \pm 21 cells vs. $114 \pm 17$ cells, respectively)

Conclusions: In our animal model of hypoxemic injury of the developing brain, sildenafil does not seem to have a significant effect on apoptotic cell death, detected by TUNEL staining technique. Evaluation of apoptosis at different times after the experimental treatment are needed to further deterrmine the effect of sildenafil on hypoxiainduced neural cell death.

\section{NATIONAL UK SURVEY OF NEONATAL CEREBRAL FUNCTION MONITORING AND COOLING FACILITIES}

V. Ponnusamy ${ }^{1}$, P. Nath ${ }^{1}$, L. Bissett ${ }^{2}$, K. Willis ${ }^{3}$, P. Clarke

${ }^{1}$ Neonatal Intensive Care, Norfolk \& Norwich University Hospitals NHS Trust, Norwich, ${ }^{2}$ Neonatal Unit, East and North Herts NHS Trust, Stevenage, ${ }^{3}$ Department of Paediatrics, The Ipswich Hospitals NHS Trust, Ipswich, UK

Background \& aims: Many reports show the benefits of routine cerebral function monitoring (CFM) in neonatal encephalopathy, and mounting recent data support the use of hypothermia therapy for perinatal asphyxia. Information is lacking regarding the current UK availability of equipment for neonatal brain monitoring and active hypothermia therapy. We aimed to survey current facilities available for brain monitoring and hypothermia therapy in UK neonatal units.

Methods: Telephone survey of all 214 UK neonatal units in July - November 2009.

Results: Responses were obtained from 214/214 $(100 \%)$ of units. Results are summarised by country (Table 1)

\begin{tabular}{|l|l|l|l|l|}
\hline & England & Scotland & Wales & N.Ireland \\
\hline $\begin{array}{l}\text { Available } \\
\text { CFM }\end{array}$ & $\begin{array}{l}41 \% \\
(73 / 179)\end{array}$ & $\begin{array}{l}47 \% \\
(7 / 15)\end{array}$ & $\begin{array}{l}30 \% \\
(4 / 13)\end{array}$ & $57 \%(4 / 7)$ \\
\hline $\begin{array}{l}\text { Cooling } \\
\text { Equipment }\end{array}$ & $\begin{array}{l}27 \% \\
(48 / 179)\end{array}$ & $\begin{array}{l}40 \% \\
(6 / 15)\end{array}$ & $\begin{array}{l}23 \% \\
(3 / 13)\end{array}$ & $42 \%(3 / 7)$ \\
\hline
\end{tabular}

[Table 1: National availability of CFM and cooling]and designation level of neonatal units (Table 2)

\begin{tabular}{|l|l|l|l|}
\hline & Level 1 & Level 2 & Level 3 \\
\hline $\begin{array}{l}\text { Available } \\
\text { CFM }\end{array}$ & $13 \%(8 / 62)$ & $33 \%(32 / 97)$ & $87 \%(48 / 55)$ \\
\hline $\begin{array}{l}\text { Cooling } \\
\text { equipment }\end{array}$ & $3 \%(2 / 62)$ & $15 \%(15 / 97)$ & $78 \%(43 / 55)$ \\
\hline
\end{tabular}

[Table 2: Comparison across levels of neonatal unit]

In total $88 / 214(41 \%)$ UK units have CFM available and $60 / 214(28 \%)$ have dedicated cooling equipment. Of tertiary neonatal intensive care units, 7/55(13\%) presently do not have available CFM equipment, and $12 / 55(22 \%)$ are not able to offer active hypothermia therapy.

Conclusion: Despite compelling evidence of the worth of cotside continuous electrical brain 